\title{
Quantification of bacterial populations in complex ecosystems using fluorescent in situ hybridization, confocal laser scanning microscopy and image analysis
}

\author{
Théodore Bouchez ${ }^{\mathrm{a}, \mathrm{c}}$, Patrick DABerT ${ }^{\mathrm{a}, *}$, Michael WAGNeR ${ }^{\mathrm{b}}$, \\ Jean-Jacques Godon ${ }^{a}$, René Moletta ${ }^{a}$
}

a Laboratoire de biotechnologie de l'environnement, Institut national de la recherche agronomique, Avenue des Étangs, 11100 Narbonne, France

b Technische Univertität München, Arcisstr. 16, D-80290 München, Germany

c ENGREF, 19 avenue du Maine, 75015 Paris, France

\begin{abstract}
A procedure for quantification of distinct bacterial populations in aggregated ecosystems was developed. It is based on fluorescent in situ hybridization coupled with confocal-laser-scanning microscopy and surface measurement of hybridized bacteria by image analysis. The proportion of a targeted bacterial species was obtained by comparison between the surface hybridized by a specific probe and the surface hybridized with a general bacterial reference probe. The accuracy of the results obtained was evaluated by direct visual counting on the same sets of images. The analytical uncertainty of the image analysis procedure was determined and depended on the threshold values selected by the operator for cutting between signal and background fluorescence. The number of fields to be analyzed for reliable quantification was also determined. This procedure allows a quantification of the proportions of bacterial species in aggregated bacterial ecosystems which gives more accurate results than visual counting because of the large number of bacteria counted. Moreover, since floc structures are preserved, it also gives information about the distribution of bacterial populations in the floc material which might reveal bacterial interactions within the community.
\end{abstract}

fluorescent in situ hybridization / bacterial quantification / image analysis / activated sludge

Résumé - Quantification des populations bactériennes des écosystèmes complexes par hybridation in situ en fluorescence, microscopie laser confocale et analyse d'image. Une procédure de quantification de populations bactériennes agrégées a été développée. Elle repose sur l'analyse d'images obtenues à

* Correspondence and reprints

E-mail: dabert@ensam.inra.fr 
l'aide d'un microscope laser confocal après hybridation in situ en fluorescence. La proportion d'une espèce bactérienne cible est obtenue par comparaison entre la surface hybridée par une sonde nucléique spécifique et la surface hybridée par une sonde générale bactérienne de référence sur une série d'images données. L'exactitude des résultats obtenus a été évaluée par comptage manuel sur les même séries d'images. L'incertitude de la procédure d'analyse d'image dépend de la taille de l'intervalle choisi par l'opérateur comme étant représentatif des seuils de niveau de gris entre signal positif et bruit de fond. Il est également possible de déterminer le nombre de champs nécessaire à prendre en compte pour obtenir une quantification valable. La procédure développée permet de quantifier les proportions des espèces bactériennes présentes dans un écosystème agrégé (flocs, biofilms...). Étant donné qu'un grand nombre de bactéries est pris en compte, les résultats obtenus sont plus précis que ceux obtenus par comptage manuel. De plus, les structures bactériennes étant préservées, il est possible d'obtenir des informations concernant la répartition des espèces au sein du floc. La nature de cette répartition peut nous aider à comprendre les interactions bactériennes au sein du floc.

\section{hybridation in situ en fluorescence / microscopie laser confocal / quantification bactérienne / analyse d'images / boues activées}

\section{INTRODUCTION}

Ecological studies on bacterial ecosystems were long restricted to the cultivable fraction of microorganisms. We know that today only $0.1 \%$ to $15 \%$ of the bacteria present in a complex ecosystem, such as soil, sediments, seawater or activated sludges, are cultivable [3]. This methodological limitation has hindered significant advances in microbial ecology of complex ecosystems. Nowadays, techniques based on $16 \mathrm{~S}$ rRNA sequences have considerably extended our knowledge in the field. These cultivation-independent techniques are commonly grouped under the designation of "rRNA approach". They encompass a characterization step, by PCR-amplification and sequencing of rDNA molecules present in an environmental sample, and a monitoring step, either by the use of sequence-specific DNA separation techniques (DGGE, SSCP, T-RFLP...) or by the use of $16 \mathrm{~S}$ rRNA targeted-oligonucleotide probes. In the latter strategy, Fluorescent In Situ Hybridization (FISH) is particularly suited to ecological studies since it enables the direct visualization of the targeted population within its environment. It thus provides useful information on the spatial organization and on the particular location of the different species in the ecosystem [7,9]. However, until now, FISH has not allowed rapid and reliable counting of aggregated bacterial populations.

Because of the aggregated nature of activated sludge, direct microscopic counting of the number of probe-targeted bacteria after FISH was always difficult and tedious. Quantification had either to be done manually by counting bacteria under the microscope (often a laborious and time-consuming process), 
or using disintegration techniques, which can damage the sample [1]. To overcome these limitations we proposed a procedure based on the computer analysis of images of hybridized bacterial surfaces. The objective of the procedure was to quantify the surface area of bacteria hybridized by a specific probe targeting the microorganisms of interest against the total surface area of bacteria hybridized with a general bacterial probe. The procedure was developed on a confocal laser scanning microscope.

\section{MATERIAL AND METHODS}

\subsection{Sample fixation}

Activated sludge samples were retrieved from laboratory-scale nitrifying reactors treating synthetic wastewater. These reactors have been described elsewhere [4]. Samples were fixed by addition of $4 \%$ paraformaldehyde phosphate buffered solution as previously described [6] except that the sample centrifugation steps were replaced by gentle filtration on nylon $0.2 \mathrm{~m}$ filters to preserve floc structure.

\subsection{Fluorescent in situ hybridization}

Fluorescent in situ hybridization with $16 \mathrm{~S}$ rRNA targeted probes and subsequent washes were performed on slides according to conventional protocols [6]. For the quantification procedure, samples were simultaneously hybridized with a specific probe of interest labeled with $\mathrm{Cy} 3$ and a general bacterial probe EUB338 labeled with Cy5. After hybridization, the slides were air dried and mounted with Citifluor anti-fading AF1 solution (CITIFLUOR Ltd, UK). Observations were performed on a confocal laser scanning microscope (Zeiss, LSM510) equipped with image analysis software (LSM510 for Windows NT4.0). For each probe pair, randomly selected microscopic fields of $1 \mu \mathrm{m}$ thickness were recorded with a $40 \mathrm{X}$ objective using the 543 and $633 \mathrm{~nm}$ laser for excitation of Cy3 and Cy5, respectively. Typically, 10 to 20 microscopic fields were captured with constant microscope parameters and gain. Images were digitized in $1024 \times 1024$ pixels, 8 bits gray. Artificial blue and red colors were applied to $\mathrm{Cy} 5$ and $\mathrm{Cy} 3$ hybridized bacteria, respectively.

The probes used in this study and their recommended hybridization stringency conditions are summarized in Table I. These probes were purchased as HPLC-purified, Cy3 or Cy5-labeled, oligonucleotide derivatives (Interaktiva, Ulm, Germany and Cybergene, Saint-Malo, France). 
Table I. Fluorescently labeled rRNA-targeted probes used in this study and recommended hybridization conditions.

\begin{tabular}{|c|c|c|c|c|}
\hline Probe name & $\begin{array}{l}\text { Probe Sequence } \\
\qquad 5^{\prime}-3^{\prime}\end{array}$ & $\begin{array}{c}\text { Targeted rRNA } \\
\text { molecule } \\
\text { and } \\
\text { E. coli position } \\
\end{array}$ & $\begin{array}{l}\% \text { formamide } \\
\text { in the } \\
\text { hybridization } \\
\text { buffer }\end{array}$ & $\begin{array}{l}\text { Targeted organisms } \\
\text { [Ref.] }\end{array}$ \\
\hline EUB338 & GCTGCCTCCCGTAGGAGT & $16 \mathrm{~S}(339-355)$ & $\$$ & Most bacteria [2] \\
\hline Alf968 & TGGTAAGGTTCTGCGCGT & $16 \mathrm{~S}(968-986)$ & 35 & $\begin{array}{c}\text { Alpha subclass of Proteobacteria } \\
\text { [8] }\end{array}$ \\
\hline GAM42a & GCCTTCCCACATCGTTT & $23 \mathrm{~S}(1027-1043)$ & 35 & $\begin{array}{c}\text { Gamma subclass of Proteobacteria } \\
{[6]}\end{array}$ \\
\hline CF319a & TGGTCCGTGTCTCAGTAC & $16 \mathrm{~S}(319-336)$ & 35 & $\begin{array}{l}\text { Cytophaga-Flexibacter cluster } \\
\qquad[9]\end{array}$ \\
\hline $\mathrm{ACA}$ & АТССТСТСССАТАСТССТА & $16 \mathrm{~S}(652-669)$ & 35 & Genus Acinetobacter $[10]$ \\
\hline NEU23a & CCCCTCTGCTGCACTCTA & $16 \mathrm{~S}(653-670)$ & 40 & $\begin{array}{l}\text { Halophilic and halotolerant members of the } \\
\text { genus Nitrosomonas [11] }\end{array}$ \\
\hline CTE & TTCСATCССCСТCTGCCG & $16 \mathrm{~S}(659-676)$ & 40 & $\begin{array}{l}\text { Used as a competitor for NEU23a } \\
{[11]}\end{array}$ \\
\hline S- $*-N$ tspa-1026-a-A-18 & AGCACGCTGGTATTGCTA & 16S (1026-1043) & 20 & $\begin{array}{c}\text { Genus Nitrospira; Nitrospira moscoviensis } \\
\text { and affiliated clones [5] }\end{array}$ \\
\hline NIT3 & CCTGTGCTCCATGCTCCG & $16 \mathrm{~S}(1030-1047)$ & 40 & Genus Nitrobacter [12] \\
\hline
\end{tabular}

$\$$ : For probe EUB338, any formamide concentration below $70 \%$ is suitable.

The probe S-*-Ntspa-1026-a-A-18 does not target Nitrospira members related to N. marina. 


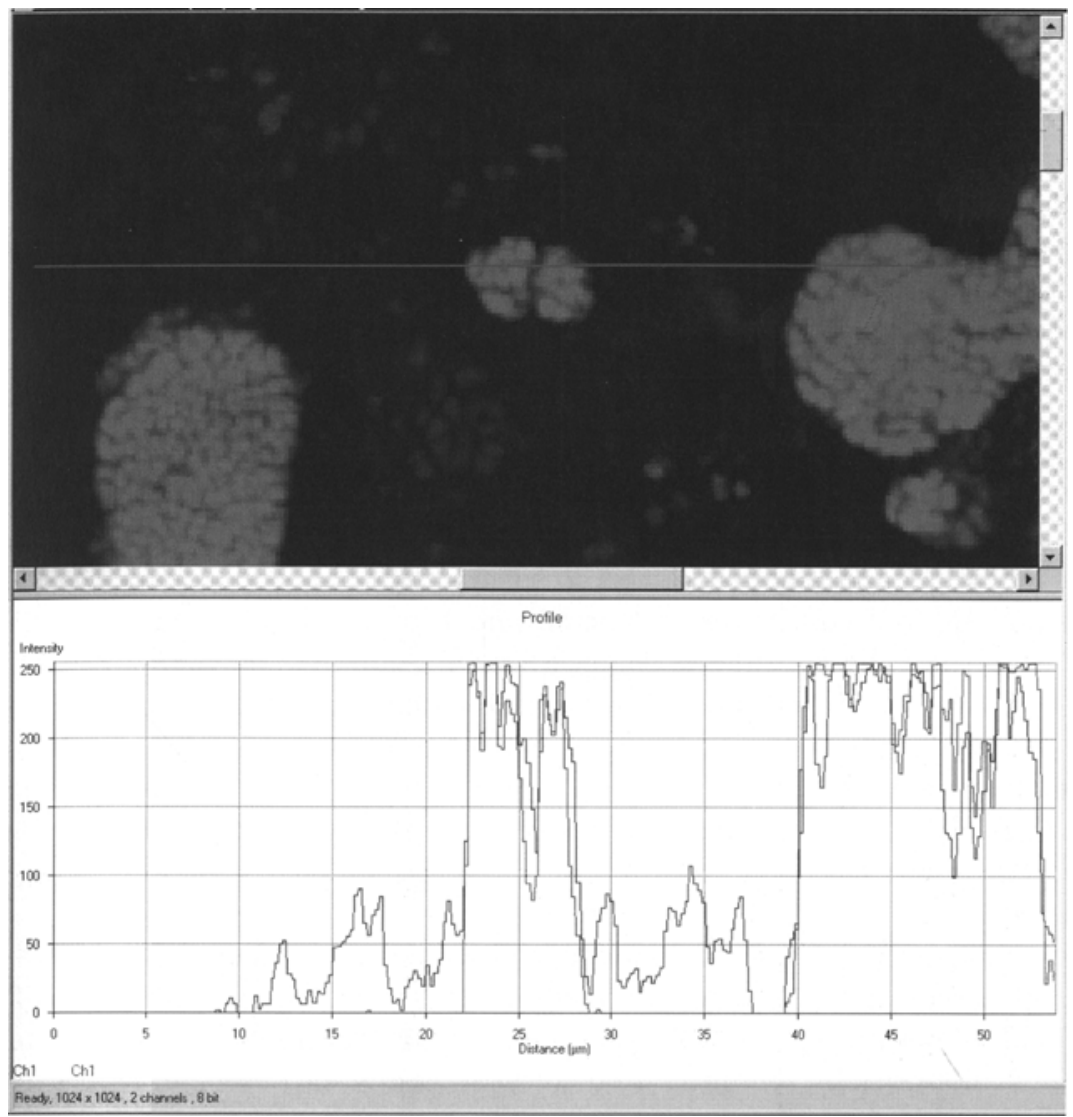

Figure 1. Determination of the threshold values for surface area measurement of she bacterial populations. Top. Zoom in of a digitized image of a nitrifying activated sludge sample simultaneously hybridized with the Cy3-labeled NEU23a probe specific of the Nitrosomonas group (red: in light grey) and the Cy5-labeled EUB338 general sacterial probe (blue: in dark grey). Bottom. Grey level profile obtained across the ight grey lane drawn on the image.

\section{RESULTS}

\subsection{Determination of the threshold values for surface area measurement of the bacterial populations}

Sludge samples were spotted on a slide and simultaneously hybridized with the Cy3-labeled NEU23a probe specific to the Nitrosomonas group of microorganisms and the Cy5-labeled EUB338 general bacterial probe. Microscopic ields were captured and digitized. A zoom in of a digitized image is shown n Figure 1 top. The non-Nitrosomonas bacteria appeared in blue, the Ni'rosomonas bacteria appeared in dark pink since they hybridized to both the 
general bacterial probe EUB338 and the specific NEU23a probe. We can see the typical tightly aggregated microcolonies formed by the Nitrosomonas bacteria.

The critical step of the surface area measurement procedure was obviously the determination of the threshold values that should be used to cut between both positive signals (Cy3 and CY5 labeled probes) and the background fluorescence. Rather than arbitrarily selecting a given value, possible intervals for threshold values were determined. On a set of 3 to 5 images, a lane was drawn across the image and a profile of intensity of the detected signals was obtained as shown in Figure 1 bottom. By comparison between the image and the gray level intensities recorded, a "conservative" threshold value, that gave a large surface area of hybridized bacteria, and a "stringent" threshold value, that minimized the surface area of hybridized bacteria, were determined. In Figure 1, the "conservative" threshold values for the blue and the red colors were set at 20 and 100 gray levels, respectively. The stringent values for the blue and the red colors were set at 50 and 170 gray levels, respectively. The surface area of the hybridized bacteria was measured using the four estimated threshold values. The four possible surface area-ratios (red-100/blue-20; red100/blue-50; red-170/blue-20 and red-170/blue-50) were calculated. The mean value of the four corresponding surface area-ratios was taken to be the final result (Tab. II). The standard error between the different ratios obtained on the same image was taken as an estimate of the uncertainty of the image analysis procedure.

For a given sample and the same hybridization experiment, we observed that the threshold values between different images were almost constant. These manually determined threshold values were therefore applied to all the images of the same series by an automated software command.

\subsection{Number of fields to be analyzed}

The number of microscopic fields required for statistically reliable quantification can be determined. It depends on the regularity of the distribution of a particular species in the floc material. An example is given in Figure 2 using a set of images (400x magnification) taken from a sludge sample hybridized simultaneously with probes Cy3-NEU23a and Cy5-EUB338. For 20 microscope fields the relative abundance of NEU23a-positive Nitrosomonas cells was computed by surface area-ratio measurements. After analysis of ten microscopic fields, stabilization of the mean value for Nitrosomonas abundance was observed (Fig. 2A). Despite the highly irregular distribution of Nitrosomonas sp. microcolonies within the flocs, the standard deviation of their relative abundance also tended to stabilize after examination of 10-12 microscopic fields (Fig. 2A). Similar results were obtained for quantification of other probedefined bacterial populations (data not shown). For some bacterial populations, e.g. members of the Cytophaga-Flexibacter cluster, stabilization of the 
Table II. Surface area measurement of the Nitrosomonas population.

\begin{tabular}{|c|c|c|c|c|c|c|c|}
\hline \multirow{3}{*}{ Fields } & \multicolumn{5}{|c|}{ NEU23a / EUB338 surface area-ratios (\%) } & \multicolumn{2}{|c|}{ Analytical error (\%) } \\
\hline & Thresholds & Thresholds & Thresholds & Thresholds & Mean & Standard & Standard \\
\hline & $170 / 20$ & $170 / 50$ & $100 / 20$ & $100 / 50$ & by field & deviation & error \\
\hline field1 & 19.8 & 22.0 & 24.3 & 27.0 & 23.3 & 2.7 & 1.3 \\
\hline field2 & 79.6 & 81.7 & 84.7 & 88.5 & 83.6 & 3.3 & 1.7 \\
\hline field3 & 51.4 & 56.6 & 62.3 & 67.7 & 59.5 & 6.1 & 3.1 \\
\hline field4 & 59.0 & 62.8 & 66.3 & 70.2 & 64.6 & 4.1 & 2.1 \\
\hline field5 & 88.6 & 91.4 & 94.1 & 96.6 & 92.7 & 3.0 & 1.5 \\
\hline field6 & 67.7 & 76.0 & 85.0 & 94.1 & 80.7 & 9.9 & 4.9 \\
\hline field 7 & 60.3 & 62.7 & 65.3 & 68.5 & 64.2 & 3.0 & 1.5 \\
\hline field8 & 96.1 & 99.8 & 103.9 & 108.3 & 102.0 & 4.6 & 2.3 \\
\hline field9 & 88.8 & 90.8 & 92.9 & 95.4 & 92.0 & 2.5 & 1.2 \\
\hline field10 & 78.9 & 82.1 & 85.5 & 89.1 & 83.9 & 3.8 & 1.9 \\
\hline field11 & 43.2 & 47.2 & 51.1 & 55.1 & 49.2 & 4.4 & 2.2 \\
\hline field12 & 76.8 & 80.4 & 84.0 & 87.6 & 82.2 & 4.0 & 2.0 \\
\hline Mean & 68.1 & 71.3 & 74.7 & 78.4 & 73.1 & 4.3 & 2.1 \\
\hline
\end{tabular}

Standard error: standard deviation $/ \sqrt{\text { number of measures effectued. }}$ 
(A)

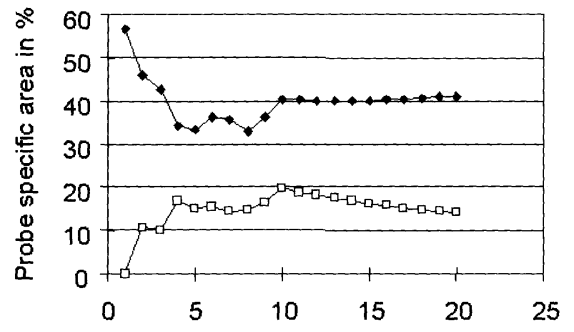

(B)

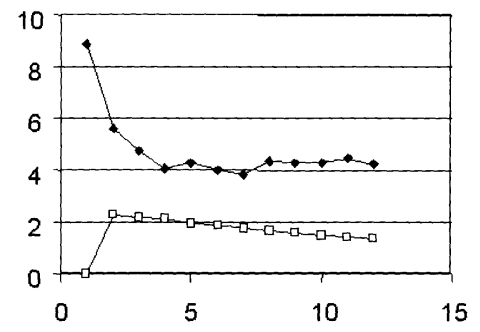

Number of fields analyzed

Figure 2. Determination of the number of fields to be analyzed. Plot, against the number of microscopic fields, of the mean value $(\$)$ and the standard deviation $(\square)$ of the surface area-ratio: (a) of cells hybridized with probe NEU23a to that of cells hybridized with the bacterial probe EUB338. (b) of cells hybridized with probe CF319a to that of cells hybridized with the bacterial probe EUB338.

mean value and of the standard deviation was achieved with fewer fields indicating a more equal distribution of these microorganisms in the floc material (Fig. 2B). Examination of 12 microscopic fields was considered to be sufficient for subsequent quantification experiments.

\subsection{Accuracy of the surface area-ratio method of counting}

To evaluate the accuracy of the surface area-ratio method for quantifying the abundance of a bacterial population, we compared the results obtained by surface area measurements with those obtained by direct manual counting. Since all the nitrifying populations monitored (Nitrosomonas, Nitrobacter and Nitrospira) formed very dense aggregates, it was not possible to count their numbers accurately. We were therefore unable to perform this comparison on nitrifying populations. The comparison was made on a sludge sample hybridized with the Cy3-labeled ACA probe specific of the genus Acinetobacter and the EUB338 probe. A $\mathrm{G}=1000$ magnification was use to allow visual counting of the bacteria in four microscopic fields. Of the 3630 bacteria counted that were hybridized with the probe Eub338, 453 (12.5\%) were also hybridized with the ACA probe. On the same set of pictures, application of the surface area-ratio method gave us a ratio of $13.9 \%$ with a standard deviation of $2.4 \%$ depending on the different values of threshold used. The manual counting fitted well with the standard deviation of the surface area-ratio measure. 


\subsection{Distribution of the different microorganisms in the floc material}

The surface area-ratio technique was used to evaluate the proportion of the different bacterial populations present in an autotrophic nitrifying reactor after stabilization of the performance of the system. Around 10,000 bacterial cells were taken into account for each field analyzed. At the time of sampling, the ecosystem was composed essentially of nitrifying bacteria (Nitrosomonas, Nitrobacter, Nitrospira) which added up to $97.9 \%$ of the microbial community hybridized area. Among them, the ammonia oxidizing bacteria Nitrosomonas seemed to be the major ones with about $70 \%$ of the hybridized bacterial area (Tab. III). The nitrite oxidizing bacteria, represented by Nitrobacter and Nitrospira, corresponded to 20.8 and $7.3 \%$ of the hybridized bacterial area, respectively.

The dispersion coefficients varied from one species to another, indicating for example that the nitrifying bacteria were more unequally distributed than members of the gamma subclass of Proteobacteria or members of the CytophagaFlexibacter cluster. Two reasons could be given to explain this difference. First, qualitative observation often reported that the nitrifying bacteria were aggregated in clusters within the floc material. Second, the probe used in the case of the gamma Proteobacteria and members from the Cytophaga-Flexibacter are more general than the genus-specific probe used for nitrifying bacteria. They could thus hybridize to a potentially more diverse population. This tends to give a more equal distribution for the total population monitored with these probes.

\section{CONCLUSIONS}

The procedure presented here is a semi-automated treatment of digitized images of activated sludge samples hybridized with bacterial rRNA targeted fluorescent probes. It quantifies the proportions of the different bacterial populations of the ecosystem and gives information about their location and distribution within the floc material. It is more rapid and more precise than manual counting because of the large number of cells taken into account. The fluorescent in situ hybridization lasts about five hours overall, and the complete analysis of one sample lasted about one hour, including the capture of about 40 images (20 fields with two dyes) and the image analysis process. Assuming that a cell has a mean apparent surface of $1 \mu \mathrm{m}^{2}$, each microscopic field analyzed $(400 \times)$ contained at least 5,000 bacteria, so that with 12 fields analyzed at least 60,000 bacterial cells were analyzed for each quantification experiment.

This procedure can be used to compare and monitor the microbial populations of complex ecosystems [4]. It should be emphasized however that the area-ratio procedure and the manual counting procedure are not measuring 
Table III. Quantification of the different bacterial subgroup present in the floc of a nitrifying reactor.

\begin{tabular}{|c|c|c|c|c|c|}
\hline Population analyzed & $\begin{array}{c}\text { Number of } \\
\text { fields analyzed }\end{array}$ & $\begin{array}{l}\text { Mean } \\
\text { Value } \\
(\%)\end{array}$ & $\begin{array}{c}\text { Mean } \\
\text { Standard error } \\
(\%)\end{array}$ & $\begin{array}{c}\text { Variance } \\
(\%)\end{array}$ & $\begin{array}{c}\text { Dispersion coefficient } \\
(\%)\end{array}$ \\
\hline Nitrosomonas & 12 & 69.8 & 2.2 & 3.9 & 5.6 \\
\hline Nitrobacter & 12 & 20.8 & 1.3 & 1.3 & 6.4 \\
\hline Nitrospira & 12 & 7.3 & 0.2 & 0.8 & 11.3 \\
\hline Alpha subclass of Proteobacteria & 14 & 25.2 & 1.1 & 1.4 & 5.6 \\
\hline Gamma subclass of Proteobacteria & 12 & 4.0 & 0.3 & 0.1 & 2.0 \\
\hline Cytophaga-Flexibacter cluster & 14 & 1.5 & 0.4 & 0.02 & 1.3 \\
\hline
\end{tabular}

Note that the percentages add up to more than $100 \%$ because Nitrobacter are members of the alpha-subclass of Proteobacteria. 
the same parameters. Manual counting gives the proportion of the targeted bacterial population in cell numbers, while the area-ratio procedure gives the proportion of the bacterial area occupied by this population on a given floc section. When the depth of the section analyzed is kept constant and the microscopic fields analyzed are chosen randomly, the area-ratio method gives an estimate of the bacterial biovolume proportion occupied by one given bacterial population. As bacterial sizes are not constant from one species to another, this proportion does not correspond to the relative numerical abundance of the targeted bacteria. This is particularly true if the same sample features a wide range of bacterial sizes (e.g., small single cells compared to large filamentous bacteria). For example, Nitrobacter and Nitrospira are much smaller than $\mathrm{Ni}$ trosomonas and for the same hybridized area-ratio their cell numbers are probably three to four times higher than that of Nitrosomonas. When population dynamics are analyzed in accordance with concomitant activity measurements of the ecosystem, it is not clear, however, what better reflects the activity of a given microbial population: the number of cells or the biovolume occupied by this specific population. Finally, within the same bacterial population, the cell biovolume may change with environmental parameters and/or the physiological state of the cell. This long list of recommendations should not discourage use of this very effective tool since, compared to other molecular destructive tools, it always allows a visual check of the cell's state in the samples.

The probe S-*-Ntspa-1026-a-A-18 was originally designed to target activated sludge clones affiliated to Nitrospira moscoviensis. However, as the attempts made to isolate these bacteria were unsuccessful, their involvement in the nitrification process was not clearly demonstrated [5]. In our reactor, operated under strictly autotrophic nitrifying conditions, the maintenance of bacteria hybridizing with this probe suggests a real implication of the Nitrospira moscoviensisrelated populations in the nitrifying activity of the ecosystem.

The extension of this procedure to conventional epifluorescence microscopy is underway. Compared to confocal laser scanning microscopy, the major problem is the thickness of the samples which results in signals originating from above and below the focus plane and interferes with the surface area measurement. Samples must be subjected to a dispersion treatment so that the cells are disposed in a single layer on the microscopic slide. The surface area-ratio measurement technique can then be applied to these partially dispersed samples. However, as the initial structures are not preserved, it is no longer possible to obtain information on the distribution of the bacterial species in the floc material.

\section{ACKNOWLEDGEMENTS}

This work has been supported by a grant from the Bureau des Ressources Génétiques. 


\section{REFERENCES}

[1] Amann R., Binder B., Olson R., Chisholm S., Devereux R., Stahl D.A., Combination of $16 \mathrm{~S}$ rRNA-targeted oligonucleotide probes with flow cytometry for analyzing mixed microbial populations, Appl. Environ. Microbiol. 56 (1990) 19191925 .

[2] Amann R., Krumholz L., Stahl D.A., Fluorescent-oligonucleotide probing of whole cells for determinative, phylogenetic, and environmental studies in microbiology, J. Bacteriol. 172 (1990) 762-770.

[3] Amann R., Ludwig W., Schleifer K.H., Phylogenetic identification and in situ detection of individual microbial cells without cultivation, Microbiol. Rev. 59 (1995) 143-169.

[4] Bouchez T., Patureau D., Dabert P., Juretschko S., Doré J., Delgenès P., Moletta R., Wagner M., Ecological study of a bioaugmentation failure, Environ. Microbiol. 2 (2000) 179-190.

[5] Juretschko S., Timmermann G., Schmid M., Schleifer K.H., Pommerening-Röser A., Koops H.P., Wagner M., Combined molecular and conventional analyses of nitrifying bacterium diversity in activated sludge: Nitrosococcus mobilis and Nitrospira-Like bacteria as dominant populations, Appl. Environ. Microbiol. 64 (1998) 3042-3051.

[6] Manz W., Amann R., Ludwig W., Wagner M., Schleifer K.H., Phylogenetic oligodeoxynucleotide probes for the major subclasses of proteobacteria: problems and solutions, Syst. Appl. Microbiol. 15 (1992) 593-600.

[7] Mobarry B., Wagner M., Urbain V., Rittmann B., Stahl D.A., Phylogenetic probes for analyzing abundance and spatial organization of nitrifying bacteria, Appl. Environ. Microbiol. 62 (1996) 2156-2162.

[8] Neef A., Anwendung der in situ Einzelzell-Identifizierung von Bakterien zur Populations analyse in komplexen mikrobiellen Biozönosen, in: Lehrstuhl für Mikrobiologie München, Technische Universität, 1997.

[9] Wagner M., Assmus B., Hartmann A., Hutzler P., Amann R., in situ analysis of microbial consortia in activated sludge using fluorescently labeled rRNA-targeted oligonucleotide probes and scanning confocal laser microscopy, J. Microsc. 176 (1994) 181-187.

[10] Wagner M., Erhart R., Manz W., Amann R., Lemmer H., Wedi D., Schleifer K.H., Development of an rRNA-targeted Oligonucleotide probe specific for the genus Acinetobacter and its application for in situ monitoring in activated sludge, Appl. Environ. Microbiol. 60 (1994) 792-800.

[11] Wagner M., Rath G., Amann R., Koops H.S., Schleifer K.H., in situ Identification of ammonia-oxidizing bacteria, Syst. Appl. Microbiol. 18 (1995) 251-264.

[12] Wagner M., Rath G., Koops H.P., Flood J., Amann R., in situ analysis of nitrifying bacteria in sewage treatment plants, Water Sci. Technol. 34 (1996) 237-244. 